\section{Table 2 (continued)}

112. Wepman, J. M., \& Hass, W. A spoken word count. Chicago: Language Research Association, 1969.

113. Whitten, W. B., Suter, W. N., \& Frank, M. L. Bidirectional synonym ratings of $\mathbf{4 6 4}$ noun pairs. Journal of Verbal Learning and Verbal Behavior, 1979, 18, 109-127.

114. Wilding, J., \& Mohindra, N. Ratings of the degree of synonymity of 279 noun pairs. British Journal of Psychology, 1981, 72, 231-240.

115. Wildina, J., \& Mohindra, N. Preferred synonyms for each noun of 279 synonym pairs. British Journal of Psychology, 1983, 74, 91-100.

116. Wollen, K. A., Cox, S. D., Conhran, M. M., Shea, D. S., \& KIRBY, R. F. Frequency of occurrence and concreteness ratings of homograph meanings. Behavior Research Methods \& Instrumentation, 1980, 12, 8-15.
117. Yatzs, J. Priming dominant and unusual senses of ambiguous words. Memory \& Cognition, 1978, 6, 636-643.

118. Zechmeister, E. B., Kina, J., Gude, C., \& Opera-Nadi, B. Ratings of frequency, familiarity, orthographic distinctiveness, and pronunciability for 192 surnames. Behavior Research Methods \& Instrumentation, 1975, 7, 531-533.

119. Zetrensten, A. A word-frequency list based on American English press reportage. Copenhagen: University of Copenhagen, 1978.

\section{REFERENCE}

Brown, A. S. Catalog of scaled verbal material. Memory \& Cognition, 1976, 4, 1S-45S.

(Manuscript received June 24, 1983; revision accepted for publication July 29,1983 .)

\title{
ANNOUNCEMENT \\ 25th Annual Meeting of The Psychonomic Society, Inc. - Change of Dates for Meeting
}

The dates for the 25th annual meeting of The Psychonomic Society, Inc., have been changed:

From-November 1-3, 1984

To-November 8-10, 1984

The meeting still will be held at the Hilton Palacio Del Rio, San Antonio, Texas. 